\title{
Improvement in commercial scale dry mill corn ethanol production using controlled flow cavitation and cellulose hydrolysis
}

\author{
David A. Ramirez-Cadavid • Oleg Kozyuk • \\ Frederick C. Michel Jr
}

Received: 19 July 2013 /Revised: 4 October 2013 / Accepted: 8 October 2013 / Published online: 31 October 2013

(C) The Author(s) 2013. This article is published with open access at Springerlink.com

\begin{abstract}
During commercial-scale dry-mill ethanol production from corn, as much as $6 \%$ of the starch and all of the cellulose remain unconverted. In this study, two methods to improve ethanol production during commercialscale corn ethanol production were tested that release and hydrolyze these unconverted carbohydrate fractions; controlled flow cavitation (CFC) and enzymatic cellulose hydrolysis. Corn slurry samples were collected from a 379 million liter per year ethanol plant in which a full-scale CFC unit was installed. Samples collected before and after the CFC unit, and after the jet cooker, were compared on three separate occasions. Results showed that CFC reduced the particle size, led to qualitative changes in cell structure, increased total sugars, and reduced total solids after liquefaction. It also led to significant increases in ethanol production and solids conversion during subsequent simultaneous saccharification and fermentation. The effects of CFC alone were greater than those of CFC plus jet cooking, possibly due to the formation of unfermentable products during jet cooking. On average, ethanol production from cavitated samples was $2.2 \%$ greater than from uncavitated samples. Cellulase addition to uncavitated and cavitated samples led to significant 3.2 and $4.3 \%$ increases in ethanol yield, respectively. The electrical energy used for CFC was $1 / 16$ th of that in the additional ethanol produced and the ethanol value was more than 38 times the cost of the additional electricity used. This indicates that CFC can both efficiently increase corn ethanol yields and reduce the amount of energy needed to produce it.
\end{abstract}

D. A. Ramirez-Cadavid • F. C. Michel Jr $(\bowtie)$

Department of Food, Agricultural and Biological Engineering, The Ohio State University, 1680 Madison Ave, Wooster, OH 44691, USA e-mail: michel.36@osu.edu

O. Kozyuk

Arisdyne Systems ${ }^{\circledR}$ LLC, 17909 Cleveland Parkway Dr, Cleveland, OH 44135, USA
Keywords Starch $\cdot$ Cellulose $\cdot$ Control flow cavitation $\cdot$ Jet cooker $\cdot$ Cellulase $\cdot$ Ethanol

\section{Introduction}

The production of corn ethanol using the dry mill process is a well-developed technology used in 2012 to produce nearly 50 billion liters of transportation fuel for the USA [1]. In this process, corn grain containing 70 to $73 \%$ starch, is milled to an average particle size of 800 to $1,000 \mu \mathrm{m}$, mixed with water and thermostable amylase enzymes to make a 30 to $34 \%$ dry matter (DM) slurry, and then heated to 82 to $85{ }^{\circ} \mathrm{C}$ to solubilize the starch. The soluble starch is then partially hydrolyzed into oligosaccharides in a process known as liquefaction. Subsequent to this, amyloglucosidase enzymes, yeast, and growth nutrients are added to simultaneously hydrolyze the soluble short-chain oligosaccharides to glucose and ferment the glucose to ethanol at 32 to $34^{\circ} \mathrm{C}$ over a period of 50 to $72 \mathrm{~h}$. Although the recovery of starch from corn in commercial plants is typically greater than $90 \%$ in this process, the conversion of the corn starch to ethanol is incomplete. As much as 5 to $7 \%$ of the original starch remains in the byproducts after fermentation [2-5].

The production of ethanol from corn has raised many concerns. One issue is its energy return on investment (EROI). Many studies have been published discussing this topic [6-12], however this value varies among studies due to the sensibility of the EROI calculations to assumptions about system boundaries, energy use in the biorefinery, estimates of energy use for corn production as well as the energy displaced by using dry distillers grains as animal feed [13]. Two other concerns are indirect land use changes [11] and life cycle greenhouse gas emissions [14], however these issues are not part of this investigation. In this investigation two methods to improve the EROI of corn ethanol production at commercial- 
scale plants are tested. The methods include improving the release and conversion of recalcitrant starch to ethanol and converting the cellulosic fraction of corn grain to ethanol. If the energy used to accomplish these tasks is substantially less than the energy contained in the additional ethanol produced, then the EROI of the overall process can be incrementally improved.

The first approach is to release residual starch using hydrodynamic cavitation [15]. Hydrodynamic cavitation occurs when cavities form inside a liquid flow, or at the boundary of a baffle body, due to a local pressure drop as the kinetic energy (velocity) of a liquid increases at the expense of pressure. If the local pressure decreases below the liquid vapor pressure, then a large number of vapor-filled cavities and bubbles are formed. As the pressure of the liquid then increases and recovers, vapor condensation takes place in the cavities and bubbles, and they collapse catastrophically, creating very large pressure impulses. According to some estimates, the temperature and pressure within collapsing bubbles can momentarily reach as high as $5,000^{\circ} \mathrm{K}$ and $180 \mathrm{MPa}$ [6-8]. Because of this high energy level, cavitation has been applied to the dispersion and disruption of materials and to improve chemical reactions [16-18].

As compared to the more well-known phenomenon of acoustic cavitation or sonication, hydrodynamic cavitation is about 40 times more efficient from an energy transfer standpoint and has been shown to be more efficient in most of the uses to which it has been applied [16, 19]. Acoustic cavitation has been reported to have beneficial effects on corn slurry properties such as increasing the particle surface area, and degradation of the crystalline parts of the starch making it more susceptible to amylase hydrolysis [15, 20,21]. Although commercial large-scale application of acoustic cavitation has been investigated as a method to improve starch yield from corn grain for ethanol production $[15,22]$, it is energy inefficient and unwieldy when scaled-up. In contrast, the scale-up of hydrodynamic cavitation equipment is much simpler, making it well suited to industrial-scale processing [23].

For these reasons, we hypothesized that hydrodynamic cavitation may provide an effective, energy-efficient, and low-cost method to facilitate the release of residual starch from corn particles in slurries at dry mill ethanol plants. Hydrodynamic cavitation applied after whole kernel milling and cooking, but before liquefaction, is a pretreatment that could be used to open or break gelatinized starch granules and remove starch adjacent to cell wall structural carbohydrates thereby marginally increasing the yield of starch and ethanol [24].

In addition to starch, corn grain also consists of small amounts of structural carbohydrates located in the cell wall including cellulose, hemicellulose, and pectin typically referred to as non-starch carbohydrates. These structural carbohydrates represent less than $20 \%$ of the total carbohydrates in the grain, but are not typically hydrolyzed by starch hydrolyzing enzymes during corn ethanol production [3, 4]. Previous studies have indicated that structural carbohydrates such as cellulose may also be inaccessible to enzymes due to the presence of residual starch adhering to the cell wall [25]. However, studies have estimated that an increase in ethanol production of almost $10 \%$ may be realized if carbohydrates (C5 and C6 sugars) in distillers grains could also be hydrolyzed and converted to ethanol in a secondary fermentation $[5,26,27]$. In this study, rather than employing additional unit operations to convert cellulosic fractions, we investigated using cellulase directly during simultaneous saccharification and fermentation (SSF) to generate additional ethanol from these fractions. Cavitation may provide an additional benefit using this strategy, by removing and solubilizing residual starch that blocks access to structural carbohydrates by cellulase-hydrolyzing enzymes.

By improving the recovery of recalcitrant starch using cavitation and adding cellulase enzymes to hydrolyze cellulose fractions in corn grain, yield increases of from $3 \%$, if recalcitrant starch is hydrolyzed to glucose, to more than $8 \%$, if both recalcitrant starch and the cellulose fraction are hydrolyzed to glucose, could potentially be realized at commercial-scale ethanol plants $[28,29]$. This could lead to significant improvements in plant profitability by reducing the amount of corn and energy needed to produce the same amount of ethanol as well as the amount of energy required to dry the fermentation byproduct known as "distillers grains", and may also positively impact the EROI.

The objective of this project was to evaluate the effects of hydrodynamic cavitation and cellulase addition during SSF on ethanol production at a commercial-scale dry mill ethanol plant. The amount of starch and cellulose released and hydrolyzed for enzymatic hydrolysis to glucose was estimated by direct measurement of soluble carbohydrates and by measuring the ethanol production after SSF of cavitated and uncavitated corn slurries with and without cellulase addition in three separate tests. To our knowledge this is the first report of a scientific investigation of the use of hydrodynamic cavitation at commercial-scale dry-mill corn ethanol plants.

\section{Materials and methods}

\subsection{Full-scale ethanol plant process}

Slurry samples were collected from a dry mill ethanol plant located near Union City, Ohio with an annual production of 379 million liter per year (100 million gallons per year). The plant was designed by ICM Inc., Kolwich KS and designed and constructed in 2004 by Fagan Inc. 
Whole kernel no. 2 yellow-dent corn was transferred from grain storage silos to a corn-cleaning system. The corncleaning system included a destoner, to remove heavies and fines, and a scalper/screener, which removed large particles and more fines. The cleaned corn was fed into hammer mills and ground using a $2.78-\mathrm{mm}$ screen.

The milled corn was conveyed to a slurry mixer where it was mixed with hot process water and transported into the first of two 94,635-L slurry tanks (slurry tanks 1 and 2) at a flow rate of $5,375 \mathrm{~L} / \mathrm{min}$. Alpha-amylase (Spezyme ${ }^{\circledR}$ Xtra, Genencor ${ }^{\circledR}$ International (now DuPont ${ }^{\mathrm{TM}}$ Genencor $^{\circledR}$ ), Palo Alto, CA) was added to the slurry in two dosages, one before the slurry tanks at a flow rate of $330 \mathrm{~mL} /$ $\mathrm{min}$, and just prior to the liquefaction tanks at $100 \mathrm{~mL} / \mathrm{min}$. The total dry solids content of the slurry was approximately $32.4 \%$ DM (Fig. 1).

The slurry was heated to $90{ }^{\circ} \mathrm{C}$ and maintained at this temperature by a shell-and-tube heat exchanger on the recirculation line. The $\mathrm{pH}$ was maintained at approximately $\mathrm{pH} 5.4$ by addition of sulfuric acid or aqueous ammonia. The residence time in each slurry tank was approximately $25 \mathrm{~min}$. The slurry leaving the second slurry tank was pumped through a CFC unit (Arisdyne, Inc.) operating at a constant pressure drop, with an inlet flow of approximately 7,192 L/min and an average energy dissipated into the slurry of $1,504.3 \mathrm{~J} / \mathrm{kg}$ (Fig. 2). The cavitation unit was constructed based on US patent 5,937,906; 5,971,601; and 6,035,897. This unit utilized a $372.8 \mathrm{~kW}$ motor that operated continuously. The electrical energy requirement for such a motor running 351 days per year would be approximately $3,141 \mathrm{MWh}$ or approximately 11,306 GJ. Experimental samples were collected from sample ports located immediately before and after the cavitation unit (Fig. 1).

After CFC, the slurry continues through cook tubes where it is heated to $115^{\circ} \mathrm{C}$ and then to liquefaction tanks. The slurry is cooled to $90{ }^{\circ} \mathrm{C}$ and a second dosage of alpha amylase is added at a flow rate of $100 \mathrm{~mL} / \mathrm{min}$ just prior to the liquefaction tanks where it remains for $2.50 \mathrm{~h}$ (Fig. 1). After liquefaction, the mash is cooled to 32 to $34{ }^{\circ} \mathrm{C}$ using a heat exchanger and sent to a 3-ML fermentor with a fill volume of 2.9-ML. After filling with liquefied slurry for $6.50 \mathrm{~h}, 295.26 \mathrm{~L}$

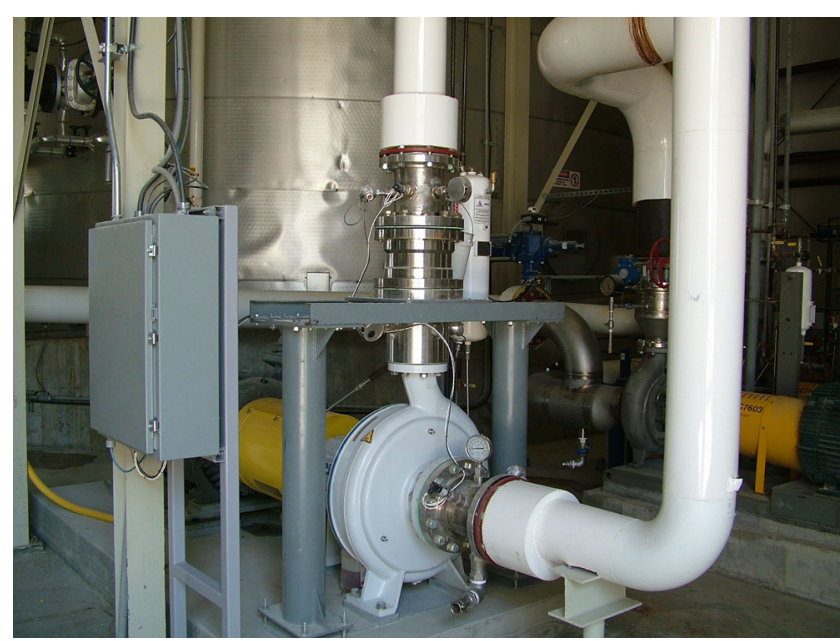

Fig. 2 Control flow cavitation unit sets up at commercial scale

of glucoamylase (Fermenzyme ${ }^{\circledR}$ L-400, Genencor ${ }^{\circledR}$ International (now DuPont ${ }^{\mathrm{TM}}$ Genencor $^{\circledR}$ ), Palo Alto, CA), $2.30 \mathrm{~kg}$ of Sentry (Ferm Solutions Inc., 445 Roy Arnold Ave. Danville, KY 40423), and $909.10 \mathrm{~kg}$ of urea are added to the tank. After $7.5 \mathrm{~h}$, yeast preculture is added which has been pre-incubated for 7 to $9 \mathrm{~h}$. The preculture contains $75 \mathrm{~kg}$ of yeast (Bio-Ferm XR, North American Bioproducts Corporation (NABC), Duluth, GA), 3.78 L of glucoamylase, $159.10 \mathrm{~kg}$ of urea, $2.3 \mathrm{~kg}$ of Sentry, $4.50 \mathrm{~kg}$ of zinc sulfate, and $4.50 \mathrm{~kg}$ of magnesium sulfate. The yeast preculture tank contains $75,708 \mathrm{~L}$ and the volume fraction of mash is $60 \%$. After the fermenter tank is half full, a second dosage of $284 \mathrm{~L}$ of glucoamylase is added. The fermenters are run for $55 \mathrm{~h}$ after inoculation.

\subsection{Slurry sample collection}

Multiple samples of slurry were collected at three different locations in three tests. One was immediately prior to the cavitation device (PreCav), the second was immediately after the CFC device (PostCav), and the third was after both CFC and a jet cooker device (PostJet). These samples were used to evaluate the effects of CFC and cellulase-hydrolyzing enzymes on
Fig. 1 Schematic of the controlled flow cavitation system location and sample ports used in this study at a commercial scale plant

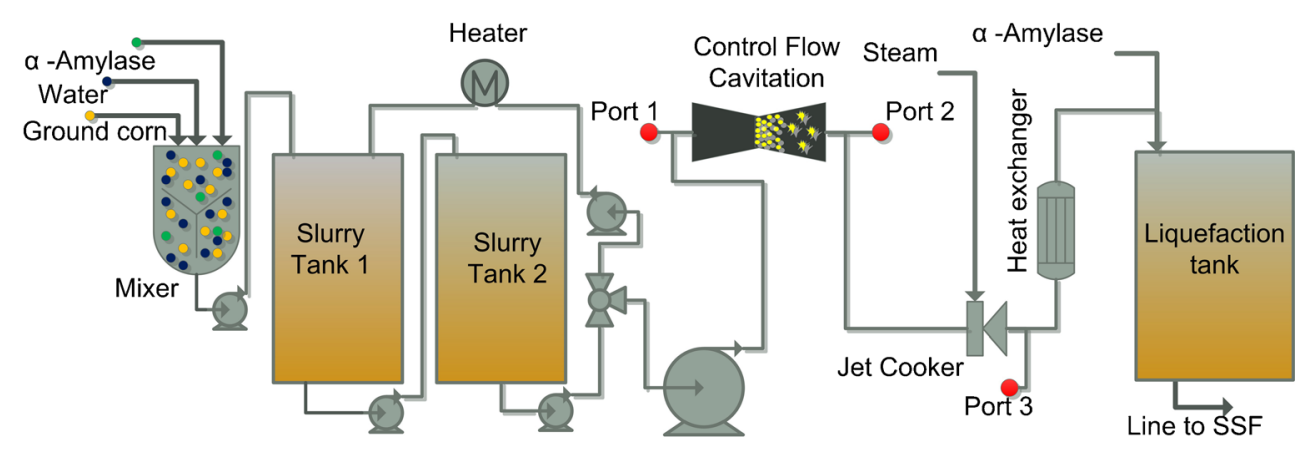


ethanol production, on various process parameters, and on the EROI of CFC.

The three tests were performed during this experiment in different weeks. The tests were independent, since from batch to batch the conditions usually change in subtle ways within the ethanol plant. Therefore, samples collected during one test were independent from the samples collected in the other tests, and as it will later be explained samples for the same port within one test are also independent among them.

Five samples of slurry were collected within each test from each of three different sample ports. One was located immediately after slurry tank 2 (PreCav, Port 1, Fig. 1), the second was located immediately after the cavitation unit but prior to the slurry cook tubes (PostCav, Port 2, Fig. 1) and the third was located just before the liquefaction tank (PostJet, Port 3, Fig. 1). The samples were collected in $1 \mathrm{~L}$ Nalgene bottles on five separate occasions over a period of $1 \mathrm{~h}$. Therefore, each sample represented an independent experimental replicate.

\subsection{Laboratory-scale fermentation}

For each of the three tests, various properties were measured to assess the impacts of cavitation and cellulase addition (Table 1). During test 1, three treatments (PreCav, PostCav, and PostJet) were evaluated at both the liquefaction and SSF stages. This test was designed to examine the effects of CFC alone on ethanol production. To examine the effects of both cavitation and cellulase addition, in tests 2 and 3, the three treatments were liquefied (PreCav, PostCav, and PostJet) and then split during SSF to evaluate the effects of cellulase enzyme addition (PreCav, PreCav+Acc, PostCav, PostCav+Acc, PostJet, and PostJet+ Acc). Since these enzymes are thermosensitive and inactivated at temperatures above $70{ }^{\circ} \mathrm{C}$, they were only added after liquefaction and were active during SSF similar to the way glucoamylases are used. These two tests were designed to evaluate SSF kinetics and the effects of both cavitation and cellulase amendment.

\subsection{Laboratory analyses}

\subsubsection{Particle size analysis}

For particle size distribution measurements, sub-samples were transferred to a $50-\mathrm{mL}$ centrifuge tube and the $\mathrm{pH}$ was reduced to $\mathrm{pH} 4.0$ using $\mathrm{H}_{2} \mathrm{SO}_{4} 2 \mathrm{~mol} / \mathrm{L}$ to inactivate alpha amylase activity. The particle size distribution was measured within 30 min using a Horiba LA-950 (Horiba Inc.) laser diffraction particle size analyzer. One-gram samples were dispersed into DI water in the analyzer and $50 \mu \mathrm{L}$ of a surfactant $(0.1 \%$ Triton X-100 in DDI water) was added to retard particle agglomeration. Particle size distribution analysis was performed using the LA-950 software provided with the device.

\subsubsection{Scanning electron microscopy analysis}

Scanning electron microscopy (SEM) analysis was performed using sub-samples from each slurry sample where the $\mathrm{pH}$ was reduced to $\mathrm{pH} 4.0$ using $\mathrm{H}_{2} \mathrm{SO}_{4} 2 \mathrm{~mol} / \mathrm{L}$ to inactivate alpha amylase activity. Samples for each experimental replicate were first rinsed three times with DDI water and then progressively dehydrated using ethanol at volume fractions of $25,50,75,90$, and $100 \%$. During the dehydration the samples were shaken for $20 \mathrm{~min}$ on a horizontal shaker at $10.5 \mathrm{rad} / \mathrm{s}$. For the final concentration of ethanol, the procedure was repeated three times. The samples were then critical point dried in a semiautomatic critical point drying apparatus (Tousimis Samdri-790). The dried samples were mounted on a stub with carbon conductive tape and sputter coated with platinum. The samples were examined with a Hitachi S-3500N scanning electron microscope.

\subsubsection{Liquefaction of slurry}

The slurry samples collected at the ethanol plant were immediately placed in a hot water bath at $90^{\circ} \mathrm{C}$ to heat them to the process liquefaction temperature. After all 15 samples had been collected, a second alpha amylase (Spezyme ${ }^{\circledR}$ Xtra, Genencor) dosage of $18 \mu \mathrm{L} / \mathrm{L}$ slurry (equal to $100 \mathrm{~mL} / \mathrm{min}$ in the process) was added and the samples were mixed by shaking. The samples were then incubated in the hot water bath for $15 \mathrm{~min}$. The samples were then removed, mixed by shaking and placed in a large styrofoam box which was subsequently filled with Styrofoam packing material and covered with a styrofoam top to maintain near adiabatic conditions during transport. The samples were transported to the OARDC laboratory in Wooster, OH. During this period the samples were periodically mixed by shaking. Upon arrival
Table 1 Matrix of analyses conducted for each test

\begin{tabular}{lllllll}
\hline Test & $\begin{array}{l}\text { Total sugars after } \\
\text { liquefaction }\end{array}$ & $\begin{array}{l}\text { Ethanol production } \\
\text { after SSF }\end{array}$ & $\begin{array}{l}\mathrm{CO}_{2} \\
\text { production }\end{array}$ & $\begin{array}{l}\text { Substrate and } \\
\text { product kinetics }\end{array}$ & $\begin{array}{l}\text { Particle size } \\
\text { analysis }\end{array}$ & SEM \\
\hline Test 1 & $\mathrm{X}$ & $\mathrm{X}$ & $\mathrm{X}$ & & & \\
Test 2 & $\mathrm{X}$ & $\mathrm{X}$ & $\mathrm{X}$ & $\mathrm{X}$ & & $\mathrm{X}$ \\
Test 3 & $\mathrm{X}$ & $\mathrm{X}$ & $\mathrm{X}$ & $\mathrm{X}$ & $\mathrm{X}$ \\
\hline
\end{tabular}


the slurry temperatures had decreased to approximately $75^{\circ} \mathrm{C}$. This process is similar to that experienced by slurry samples at the commercial plant during liquefaction and fermentation tank filling.

\subsubsection{Simultaneous saccharification and fermentation}

Upon arrival at the laboratory, one 100-g aliquot (test 1) or two 100 -g aliquots (test 2 and 3 ) of each hot slurry sample were removed and transferred into tarred, autoclaved $250-\mathrm{mL}$ Erlenmeyer flasks equipped with sterilized rubber stoppers and gas locks containing autoclaved DI water. The samples were allowed to cool to $32{ }^{\circ} \mathrm{C}$. SSF experiments were conducted as described previously by Dowe and McMillan [30] and Montalbo-Lomboy [15] with some variations: Stock media and solutions were prepared and stored at $4{ }^{\circ} \mathrm{C}$. The $10 \times$ YP medium was prepared by mixing $100 \mathrm{~g}$ of yeast extract, $200 \mathrm{~g}$ of peptone and DDI water to a total volume of $1 \mathrm{~L}$. The medium was sterilized by autoclaving for $20 \mathrm{~min}$ at $137.9 \mathrm{kPa}$. YP medium with $5 \%$ of glucose was prepared by mixing $10 \mathrm{~g}$ of yeast extract, $20 \mathrm{~g}$ of peptone, $50 \mathrm{~g}$ of dextrose, and $1,000 \mathrm{~mL}$ of sterilized DDI water. The medium was filter sterilized. Citrate buffer $(1 \mathrm{~mol} / \mathrm{L}, \mathrm{pH} 4.5)$ was prepared by mixing $192 \mathrm{~g}$ of anhydrous citric acid with $1,000 \mathrm{~mL}$ of DDI water and titrating with a solution $10 \mathrm{~mol} / \mathrm{L}$ of $\mathrm{NaOH}$ to a $\mathrm{pH}$ of 4.3. The solution was sterilized by autoclaving for $20 \mathrm{~min}$ at $137.9 \mathrm{kPa}$.

Yeast pre-cultures were grown in yeast propagation medium prepared by mixing $100 \mathrm{mg}$ of dry industrial Sacharomyces cerevisiae (Bio-Ferm XR, NABC, the same variety used at the commercial plant), $100 \mathrm{~mL}$ of YP medium with $5 \%$ glucose, $10 \mathrm{~mL}$ of citrate buffer, and $40 \mathrm{~mL}$ of sterilized DI water to give a total volume of $150 \mathrm{~mL}$. The medium was placed in a 1-L Erlenmeyer flask, sealed with cotton stoppers, and incubated at $32{ }^{\circ} \mathrm{C}$ for 18 to $20 \mathrm{~h}$ with shaking at $13.8 \mathrm{rad} / \mathrm{s}$ [15].

For all the tests, SSF was initiated by amending each of the slurry samples $(100 \mathrm{~g})$ with $10 \mathrm{~mL}$ of $10 \times \mathrm{YP}$ medium, $80 \mu \mathrm{L}$ of glucoamylase (GC 019, Genencor), $10 \mathrm{~mL}$ of the yeast preculture, and $700 \mu \mathrm{L}$ of sterilized DDI water. For tests 2 and 3, the second set of the slurry samples was amended the same way except that $700 \mu \mathrm{L}$ of a cellulose-hydrolyzing enzyme complex (Accellerase ${ }^{\circledR} 1500$, Genencor $^{\circledR}$ ) was added in place of the $700 \mu \mathrm{L}$ of DDI water. A total of three treatments were tested for test 1: PreCav (control), PostCav, and PostJet; for tests 2 and 3, six different treatments were tested: PreCav (control), PostCav, PostJet, PreCav plus cellulase, PostCav plus cellulase, and PostJet plus cellulase. Similarly three and six negative controls were used, for test 1 and tests 2 and 3 , respectively, that received $100 \mathrm{~g}$ of sterilized DI water in place of slurry. The cultures were incubated at $34{ }^{\circ} \mathrm{C}$ for $72 \mathrm{~h}$ with shaking at $18.8 \mathrm{rad} / \mathrm{s}$ in an orbital shaker.
The cellulase enzyme complex (Accellerase ${ }^{\circledR}$ 1500) consisted of endoglucanase, beta-glucosidase, and other enzymes that digest non-starch carbohydrates found in lignocellulosic biomass, such as cellulose, hemicelluloses, and beta-glucans. It is produced by a genetically modified strain of Trichoderma reesei and has an endoglucanase activity of 2,200 to 2,800 CMC U/g and a beta-glucosidase activity of 525 to $775 \mathrm{pNPG} \mathrm{U/g}$. One CMC U unit of activity liberates $1 \mu \mathrm{mol}$ of reducing sugar (expressed as glucose equivalents) in $1 \mathrm{~min}$ under specific conditions of $50^{\circ} \mathrm{C}$ and $\mathrm{pH}$ 4.8. One pNPG unit denotes $1 \mu \mathrm{mol}$ of nitrophenol liberated from para-nitrophenyl- $B$-D-glucopiranoside per minute at $50{ }^{\circ} \mathrm{C}$ and $\mathrm{pH} 4.8$.

\subsubsection{Substrate and product measurement}

For the test 1 , after the liquefaction $2-\mathrm{mL}$ samples were collected from each Nalgene bottle. At the end of the fermentation $(72 \mathrm{~h}) 2-\mathrm{mL}$ samples were collected from each Erlenmeyer and stored at $4{ }^{\circ} \mathrm{C}$ for later analysis and Erlenmeyer flasks were weighed. For tests 2 and 3 after the liquefaction 2-mL samples were also collected from each Nalgene bottle and also from each flask during fermentation after $0,12,24,44,60$, and $72 \mathrm{~h}$ and 0,12 , 29, 41, 60, and 72 h, respectively. For each sampling, 2$\mathrm{mL}$ samples were collected and stored at $4{ }^{\circ} \mathrm{C}$ and the total mass of each fermentation flask plus beer was measured before and after each collection.

Each sample during the tests was analyzed for the concentrations of substrates (glucose, maltose, DP3, and DP4+, where "DPx" represent glucose oligomers with " $\mathrm{x}$ " subunits) and products (ethanol, glycerol, lactic acid, and acetic acid) using an Agilent 1200 chromatography system (Agilent Technologies Corporation) equipped with a Rezex ROA-Organic acid $\mathrm{H}+(8 \%)$ column (Phenomenex ${ }^{\circledR}$ ) and security guard column (Phenomenex ${ }^{\circledR}$ ), automated sampler, and refractive index detector.

Samples were prepared for HPLC by centrifugation to remove large solids, followed by filtration through $0.45-\mu \mathrm{m}$ syringe filters into $2-\mathrm{mL}$ HPLC vials. HPLC was conducted using a $0.0025 \mathrm{~mol} / \mathrm{L} \mathrm{H}_{2} \mathrm{SO}_{4}$ mobile phase at a flow rate of $0.6 \mathrm{~mL} / \mathrm{min}$ and an injection volume of $10 \mu \mathrm{L}$. The column temperature was $80{ }^{\circ} \mathrm{C}$. The system was calibrated using a six-point calibration of standard mixtures (Fuel Ethanol Residual Saccharides Mix, 48468-U, Supelco). Chemstation software (Agilent Technologies Corporation) was used to determine peak areas and calculate analyte concentrations based on the calibration curves.

For test 3 , before and after fermentation, the final concentrations of total dry solids were measured gravimetrically using a convection oven [31]. 


\subsection{Statistical analysis of laboratory data}

The effects of the three treatments PreCav, PostCav, and PostJet after liquefaction and PreCav, PreCav+Acc, PostCav, PostCav+Acc, PostJet, and PostJet+Acc after SSF were compared using one-way ANOVA at the $95 \%$ confidence level for a single factor (treatment) at three and six levels with a completely randomized design of each of the response variables (a total of 10). Parameters with significant difference $(P$ value $<0.05)$ were analyzed with TukeyKramer's HSD test to identify the pairs with significant differences. All statistical analyses were conducted in JMP Pro 9.0.

\section{Results and discussion}

\subsection{Effects of cavitation on corn particle size distribution}

The particle size distribution of corn slurry at dry-milling ethanol plants is dependent on the type of mill used, the screen size, and the corn kernel hardness (hard or soft). Most plants use hammer mills containing screens with relatively small openings [5]. The effects of cavitation on the particle size distribution of corn slurry was determined by comparing the particle size distribution in cavitated slurry samples (PostCav and PostJet) to the particle size distribution in uncavitated samples (PreCav) on three separate occasions. For all three tests, whole kernel no. 2 yellow-dent corn was hammer-milled at a commercial-scale plant and passed through a $2.78 \mathrm{~mm}$ (7/ 68 inch) screen. The milled corn was transported to a mixer and hot water and alpha-amylase were added to create slurry. The slurry was then cooked then passed through a controlled flow cavitation unit.

The particle size distributions for the three treatments are depicted in the Fig. 3. PreCav (the control treatment), showed two peaks. The apex of the peaks was centered at 11 and $900 \mu \mathrm{m}$. These sizes are commonly obtained after corn hammer milling. Particles falling into the largest peak are called "cornmeal" or "regular grits" [32] and those in the smallest peak correspond to individual starch granules, cell clusters forming large pieces, starch granule clusters, and or broken starch granule pieces [33]. Cavitated treatments (PostCav and PostJet) showed the same two groups of peaks (Fig. 3). However, there was a significant reduction in the largest particle size group and a significant increase of the smallest particle size group indicating that the grits fraction had been converted to individual starch granules in the slurry. It is also likely that some starch granule clusters and granule pieces were solubilized, due to cavitation treatment since the amount of solids was reduced after cavitation (Table 2). These effects may have contributed to increased starch release and its hydrolysis in PostCav and PostJet samples by increasing

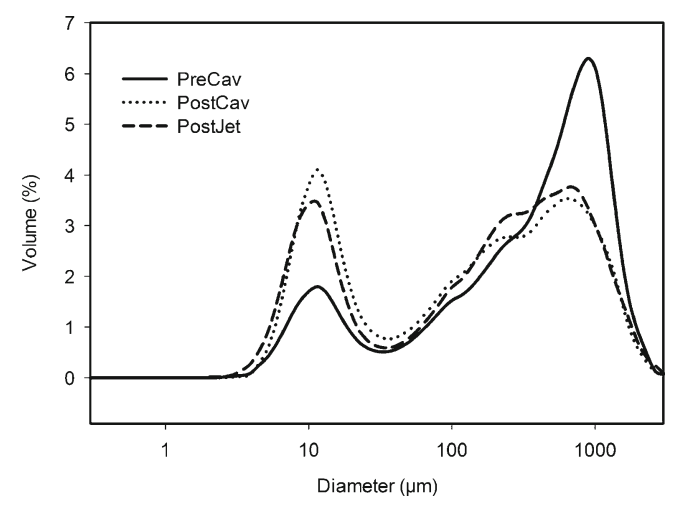

Fig. 3 Particle size distributions for uncavitated (PreCav), cavitated (PostCav) and cavitated and jet cooked (PostJet) corn slurries at a commercial scale plant

DP4+, maltotriose, and maltose concentrations in the liquefied slurry (Fig. 5).

\subsection{Scanning electron microscopy analysis}

In order to gain insights into the effects of cavitation and the jet cooker on morphological aspects of the samples, PreCav, PostCav, and PostJet samples were examined using SEM at a range of magnifications during test 3 . Only magnifications of $\times 150$ and $\times 300$ are shown (Fig. 4). A total of six different samples from each treatment were observed and the most common effects are shown (Fig. 4). At $\times 150$ magnification the dimensions of the corn regular grits are clearly evident (approximately $750 \mu \mathrm{m}$ ), especially in Fig. 4a and c. Comparison of SEM images at $\times 150$ showed that cavitation resulted in superficial damage to the corn particle surfaces and cell walls (Fig. 4c and e). For the uncavitated samples, cell structures were clearly evident and strongly delineated (Fig. 4a), while in both cavitated samples (PostCav and PostJet) they were frayed and much less evident (Fig. 4c and e). This phenomenon may have been the result of shear forces generated during hydrodynamic cavitation [19]. An effect observed only on the particles in the PostJet samples was the presence of flakes coating the surface. These likely consisted of gelatinized starch created at elevated temperatures.

Images at $\times 300$ magnification showed similar effects of cavitation (Fig. 4b, d, and f). In addition, the PreCav samples

Table 2 Slurry solids in percentage of dry matter (\% DM) before and after commercial scale controlled flow cavitation treatment and after cavitation and jet cooking, after sampling

\begin{tabular}{ll}
\hline Treatment & Slurry solids \% DM \\
\hline Control (PreCav) & $29.9 \pm 1.6$ \\
Cavitation (PostCav) & $26.2 \pm 0.4$ \\
Cavitation+Jet Cook (PostJet) & $25.3 \pm 0.9$ \\
\hline
\end{tabular}


Fig. 4 SEM images of corn slurry samples from a commercial scale ethanol plant. $\mathbf{a}$ and $\mathbf{b}$ before cavitation (PreCav) at $\times 150$ and $\times 300$ of magnification. $\mathbf{c}$ and $\mathbf{d}$ after cavitation (PostCav) at $\times 150$ and $\times 300$ of magnification. $\mathbf{e}$ and $\mathbf{f}$ after cavitation and jet cooking (PostJet) at $\times 150$ and $\times 300$ of magnifications
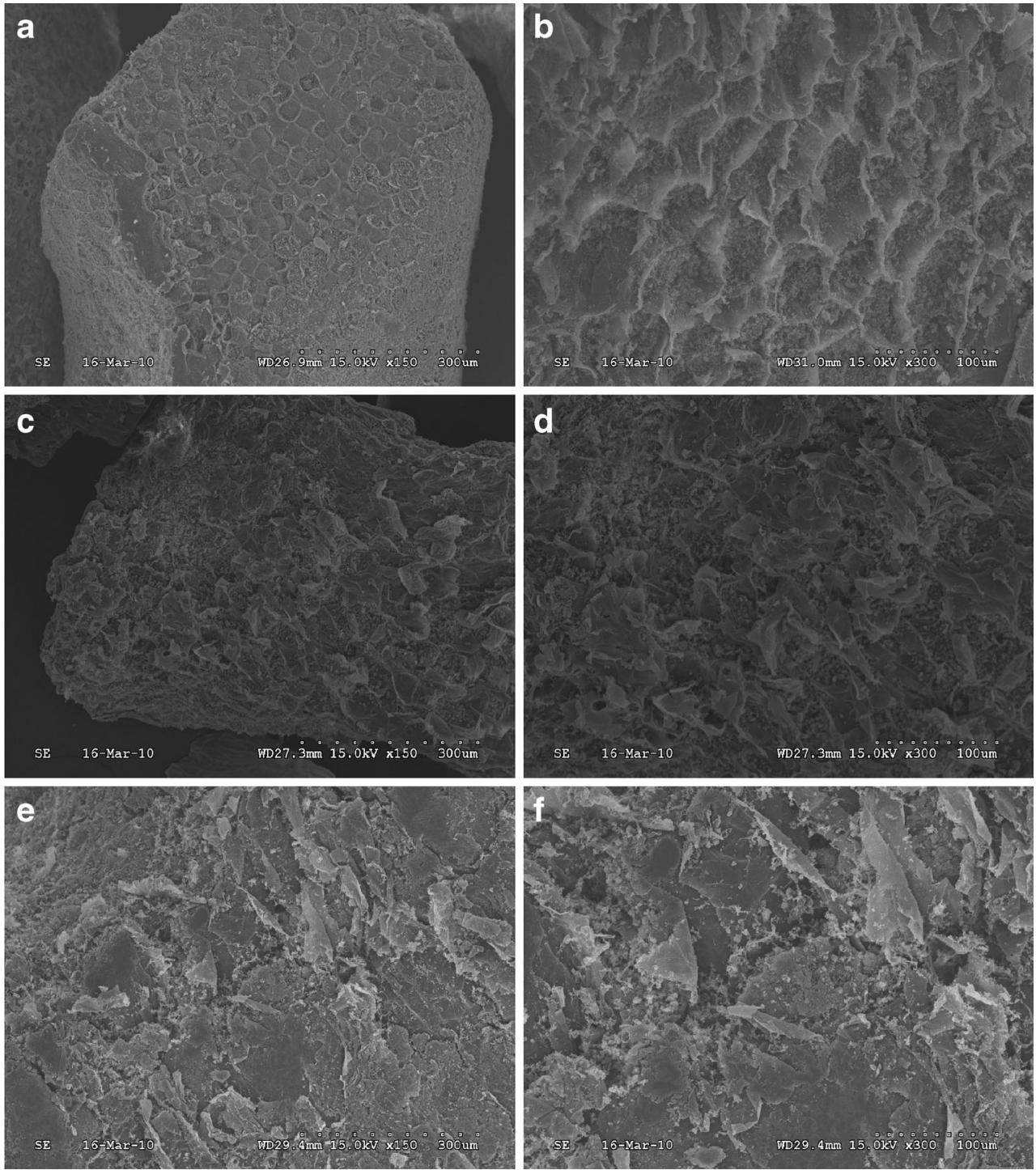

(Fig. 4b) showed that the starch granules were mostly dispersed and that starch was found in tiny clusters still adhering to the cell walls. This indicates that most starch granules are broken but are still linked together by proteins as is commonly observed in raw corn starch [34]. Damaged starch granules may be a product of the swelling and weakening of granules by water and temperature, as well as the hydrolysis of starch by alpha amylase enzymes added during this process. Despite this, some starch granules remained in their original round or polyhedral form likely as a function of their origin from soft or hard corn endosperm, respectively. Similar formations were found by Ma [35] during liquefaction of corn starch. In PostCav samples (Fig. 4d), these tiny groups of starch and starch granules were still noticeable, but their amount decreased on the frayed cell walls, possibly because starch was either released or gelatinized, or both and they became available to amylase enzymes. This may be why an increase in sub-products was observed after liquefaction (Table 3). Therefore, the reduction in the amount of these tiny aggregations of starch was a possible effect of cavitation, and the increase of sub-product could be due to availability of free starch to be hydrolyzed by alpha-amylase enzyme. In the PostJet samples (Fig. 4f), gelatinized starch flakes were also evident, and tiny groups of starch were less noticeable. Starch granules were still seen, however they were a minor component as compared to the PostCav samples. This may indicate that they had already been gelatinized and hydrolyzed.

It is important to note that SEM observations of many particles of different sizes were made, and structural impacts such cell wall fragmentation were clearly visible on particles of regular corn grits (largest size particles). For the smallest particles, corresponding to starch granules or broken starch granules clustered in tiny starch groups or a combination of 
Table 3 Properties of PreCav (control), PostCav (cavitated), and PostJet (cavitated+jet cooked) corn slurries after liquefaction on three separate occasions (tests 1 to 3 )

\begin{tabular}{lllllll}
\hline Test & Treatment & Ethanol $(\mathrm{mg} / \mathrm{mL})$ & DP4 $+(\mathrm{mg} / \mathrm{mL})$ & DP3 $(\mathrm{mg} / \mathrm{mL})$ & Maltose $(\mathrm{mg} / \mathrm{mL})$ & Glucose $(\mathrm{mg} / \mathrm{mL})$ \\
\hline Test 1 & PreCav & $3.8 \pm 0.1 \mathrm{a}$ & $176.1 \pm 1.0 \mathrm{a}$ & $27.3 \pm 0.2 \mathrm{a}$ & $29.6 \pm 0.3 \mathrm{a}$ & $8.6 \pm 0.1 \mathrm{a}$ \\
& PostCav & $3.9 \pm 0.1 \mathrm{a}$ & $180.5 \pm 3.8 \mathrm{~b}$ & $28.2 \pm 0.7 \mathrm{a}$ & $30.4 \pm 0.5 \mathrm{~b}$ & $8.7 \pm 0.4 \mathrm{a}$ \\
& PostJet & $3.6 \pm 0.1 \mathrm{a}$ & $178.9 \pm 0.6 \mathrm{ab}$ & $28.2 \pm 0.5 \mathrm{a}$ & $30.9 \pm 0.1 \mathrm{~b}$ & $8.7 \pm 0.0 \mathrm{a}$ \\
Test 2 & PreCav & $3.9 \pm 0.3 \mathrm{a}$ & $196.4 \pm 0.5 \mathrm{a}$ & $33.3 \pm 0.3 \mathrm{a}$ & $32.0 \pm 0.2 \mathrm{a}$ & $11.8 \pm 0.1 \mathrm{a}$ \\
& PostCav & $3.8 \pm 0.1 \mathrm{a}$ & $199.3 \pm 1.9 \mathrm{~b}$ & $34.2 \pm 0.5 \mathrm{ab}$ & $32.5 \pm 0.4 \mathrm{a}$ & $11.2 \pm 0.1 \mathrm{~b}$ \\
& PostJet & $4.0 \pm 0.0 \mathrm{a}$ & $198.8 \pm 1.0 \mathrm{~b}$ & $34.7 \pm 0.8 \mathrm{~b}$ & $32.8 \pm 0.5 \mathrm{a}$ & $10.9 \pm 0.2 \mathrm{c}$ \\
Test 3 & PreCav & $2.9 \pm 0.3 \mathrm{ab}$ & $198.8 \pm 0.9 \mathrm{a}$ & $30.7 \pm 0.7 \mathrm{a}$ & $24.4 \pm 1.0 \mathrm{a}$ & $7.2 \pm 0.3 \mathrm{a}$ \\
& PostCav & $3.2 \pm 0.1 \mathrm{~b}$ & $202.3 \pm 1.9 \mathrm{~b}$ & $32.4 \pm 0.5 \mathrm{~b}$ & $25.7 \pm 0.8 \mathrm{a}$ & $7.4 \pm 0.7 \mathrm{a}$ \\
& PostJet & $2.8 \pm 0.1 \mathrm{a}$ & $201.5 \pm 2.0 \mathrm{~b}$ & $32.4 \pm 1.1 \mathrm{~b}$ & $25.3 \pm 1.0 \mathrm{a}$ & $7.4 \pm 0.4 \mathrm{a}$ \\
\hline
\end{tabular}

Values are means $(n=5)$ plus or minus one standard deviation. ANOVA was applied for each test at each compound and Tukey-Kramer's HSD test was conducted to identify difference among treatments. The same letter in each compound for each test denotes a homogenous group at level of significance of $5 \%$

these (data not shown) the effect of cavitation was less evident. This and previous results for the particle size distribution analysis suggest that hydrodynamic cavitation has effects on both the small and large particle sizes. One is by reducing the particle size of the smaller particles and disrupting the structure of larger particles leading to the release of residual starch into the slurry. This starch is then exposed and therefore more easily hydrolyzed resulting in a decrease in total solids (see Tables 2 and 4), and an increase in total glucose after liquefaction as shown in Table 3 and Fig. 5.

\subsection{Effects of cavitation on carbohydrates liberated} during slurry liquefaction

The carbohydrates and other soluble products present after slurry liquefaction from each of the three treatments (Pre Cav, PostCav, and Post Jet) were quantified for the three separate tests by HPLC. Each test was analyzed independently from the others by ANOVA, and when a significant difference was found, a Tukey-Kramer's HSD test was conducted.

The main products of the liquefaction are saccharides or carbohydrates, such as DP4+, DP3, and maltose. Other compounds like glucose, lactic and acetic acid, glycerol, and

Table 4 Slurry solids in percentage of dry matter ( $\%$ DM) before and after commercial scale controlled flow cavitation treatment and after cavitation and jet cooking, after liquefaction

\begin{tabular}{ll}
\hline Treatment & Slurry solids \% DM \\
\hline Control (PreCav) & $20.4 \pm 1.2$ \\
Cavitation (PostCav) & $18.8 \pm 1.2$ \\
Cavitation+Jet Cook (PostJet) & $19.5 \pm 1.3$ \\
\hline
\end{tabular}

ethanol were also present in the samples after the liquefaction. However, their presence is related to the use of backset in ethanol plants, and they are not products of the liquefaction itself. Therefore the statistical analysis was conducted on main compounds including glucose and ethanol, since they are factors directly impacting the ethanol production during SSF, others compounds were quantified but they are not shown. Additionally, the amount of glucose yield from all of the saccharides was estimate and compared for all the treatments.

Results for total carbohydrates, glucose, and ethanol concentration for the three tests were different due to the inherent variability of the ethanol production process at commercial scale (Table 3). Some of the variability likely is due to differences in the raw corn material, while others may be due to differences in plant operating parameters and/or materials, among others. For example, Wu et al. [36] mentioned how the ethanol production and the rate of conversion may be affected by the bioavailability of the starch among grain cultivars. This variability was the reason that three independent tests were conducted to examine the effects of CFC. Khanal et al. [33] also reported that glucose release during ultrasound pretreatments was variable as a result of process parameters and feedstock characteristics.

After liquefaction, the cavitated samples (PostCav) had significantly higher concentrations of DP4+ in all the tests as compared to uncavitated samples (PreCav). Increases of 2.51, 1.50 , and $1.77 \%$ were observed for tests 1,2 , and 3 , respectively (Table 3). Cavitation treatment (PostCav) also significantly increased the total carbohydrate concentration after liquefaction as compared to the uncavitated treatment. During tests 1, 2, and 3, the total sugar concentration increased by $2.61,1.40$, and $2.51 \%$, respectively (Fig. 5). Low concentrations of ethanol were measured at this stage, but these were not significantly different within treatments. In test 


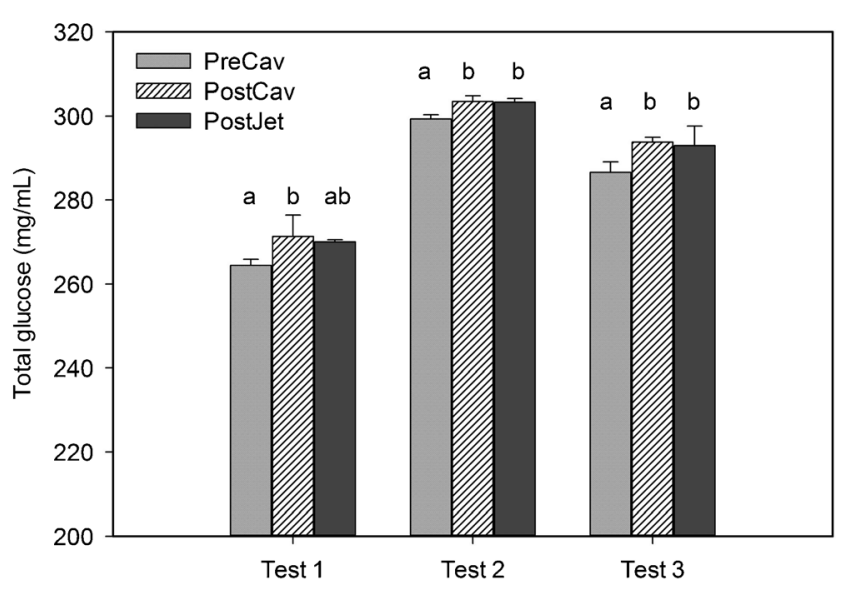

Fig. 5 Total glucose after liquefaction. Sum of DP4+, DP3, maltose, and glucose concentrations after liquefaction for PreCav, PostCav, and PostJet treatments in three tests. Total glucose was calculated as the sum of DP4+ $* 1.11+\mathrm{DP} 3 * 1.07+$ maltose* $1.05+$ glucose. Values are means $(n=5)$ plus or minus one standard deviation. Concentration values are in units of $\mathrm{mg}$ of glucose per milliliter of slurry. ANOVA was applied for each test at each compound and Tukey-Kramer's HSD test was conducted to identify difference among treatments. The same letter in each compound for each test denotes a homogenous group at level of significance of $5 \%$

3, ethanol concentration was higher in the PostCav treatment as compared to PostJet, but this difference was taken into account when analyzing ethanol production after SSF.

The PostJet samples also showed significantly higher total sugars than the uncavitated control. But the increase was not significantly different for jet cooking as compared to the cavitation alone treatment. For all three tests, the PostCav and PostJet samples were part of the same homogenous group (Table 3). ANOVA confirmed that there was a statistical difference between cavitated and uncavitated samples $(P$ value $<0.05)$, whereas there was no difference between the two cavitated treatments (PostCav and PostJet). This implies that cavitation plus jet cooking does not increase saccharides concentration after liquefaction as compared to cavitation alone.

PostCav and PostJet treatments also showed lower total solids concentrations as compared to uncavitated samples after liquefaction (Table 4). These results support the sugar analysis findings since the solid concentration would be expected to decrease as more starch is hydrolyzed to saccharides. The slightly greater solids concentration for the PostJet treatment as compared to the PostCav treatment may be due to the formation of a starch gel at the high temperatures in the jet cooker [37] causing that oligosaccharides were retained in the solid fraction during solid and liquid fraction separation.

\subsection{Effects of cavitation and cellulase addition on SSF products}

The effect of cavitation on SSF products was measured on three separate occasions (tests 1, 2, and 3). During test 1, ethanol, oligossacharides, and glucose concentrations were measured after $72 \mathrm{~h}$ of SSF. In addition, the weight loss during fermentation was measured to quantify carbon dioxide production (Table 5). For this test, there was a significant increase of $1.5 \%$ in the ethanol production in the PostCav treatment as compared to the PreCav treatment. The PostJet treatment exhibited higher ethanol productions than the uncavitated treatment, but the difference was not significant (Table 5). The increases were similar in magnitude to the increases in total sugars observed in the PostCav and PostJet treatments after liquefaction (Fig. 5).

For tests 2 and 3, the effects of both cavitation and cellulase addition during SSF were determined. After liquefaction, one set of the slurry samples was amended with cellulosehydrolyzing enzymes while another set was not amended. This gave a total of six treatments for each test. Five replicates for each of the different treatments was used as well as six negative controls. The cultures were fermented for $72 \mathrm{~h}$ and the concentrations of carbohydrates and fermentation products were measured during the course of the fermentation (Fig. 6). The final total solids were also analyzed for test 3 .

Time courses for substrates and products during the SSF for tests 2 and 3 showed that after $12 \mathrm{~h}$, the concentrations of oligosaccharides (DP4+ and DP3) had decreased to low levels (Fig. 6). Glucose concentration peaked in concentration after $12 \mathrm{~h}$ of fermentation then dropped to low levels in the 24 and $29 \mathrm{~h}$ samplings during tests 2 and 3, respectively (Fig. 6a and c). After $12 \mathrm{~h}$, the glucose concentrations were greatest in the cavitated treatments, PostCav, and PostJet were 82.7 and $86.5 \mathrm{mg} / \mathrm{mL}$ for test 2 and 74.3 and $80.6 \mathrm{mg} / \mathrm{mL}$ for test 3 , respectively, were observed. In the cellulase-amended treatments, glucose concentrations were also highest after $12 \mathrm{~h}$. Concentrations of 82.1 and $85.0 \mathrm{mg} / \mathrm{mL}$ were observed for the PostCav+Acc and PostJet+Acc treatments in test 2 as compared to $77.2 \mathrm{mg} / \mathrm{mL}$ in the PreCav treatment. In test 3, 73.5 and $81.6 \mathrm{mg} / \mathrm{mL}$ were observed for the PostCav+Acc and PostJet+Acc treatments while $62.9 \mathrm{mg} / \mathrm{mL}$ was observed in the PreCav control. The ethanol concentration reached a

Table 5 Effects of PreCav (control), PostCav (cavitated), and PostJet (cavitated+jet cooked) on ethanol, $\mathrm{CO}_{2}$ production, and ethanol increase for test 1

\begin{tabular}{llll}
\hline Treatment & Ethanol $(\mathrm{mg} / \mathrm{mL})$ & $\mathrm{CO}_{2}(\%)$ & Ethanol increase (\%) \\
\hline SSF after 72 test 1 & & \\
PreCav & $110.8 \pm 0.7 \mathrm{a}$ & $11.2 \pm 0.3 \mathrm{a}$ & - \\
PostCav & $112.5 \pm 0.9 \mathrm{~b}$ & $11.6 \pm 0.4 \mathrm{a}$ & 1.5 \\
PostJet & $112.0 \pm 0.4 \mathrm{ab}$ & $11.2 \pm 0.0 \mathrm{a}$ & 1.1 \\
\hline
\end{tabular}

Values are means $(n=5)$ plus or minus one standard deviation. ANOVA was applied for each test at each compound and Tukey-Kramer's HSD test was conducted to identify difference among treatments. The same letter in each compound for each test denotes a homogenous group at level of significance of $5 \%$ 

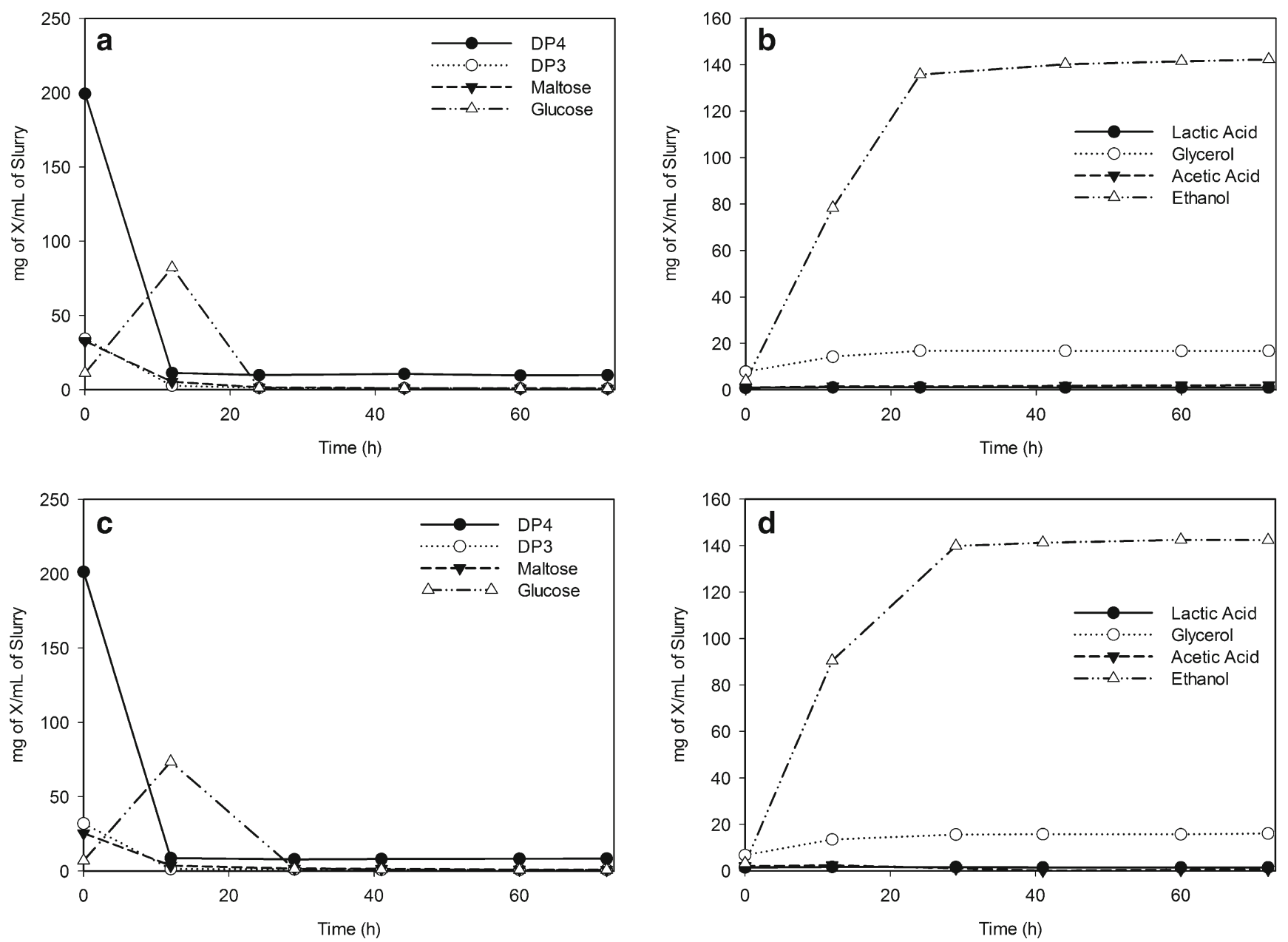

Fig. 6 Kinetics of substrate utilization $(\mathbf{a}-\mathbf{c})$ and product formation $(\mathbf{b}-\mathbf{d})$ during SSF during tests 2 and 3. Only the PostCav + Acc treatment is shown

maximum after 24 and $29 \mathrm{~h}$ of fermentation in tests 2 and 3, respectively, and thereafter increased insignificantly. Glycerol increased during the first $12 \mathrm{~h}$ then no significant changes in concentration were observed. This compound is commonly produced at the beginning of yeast fermentations to maintain redox balance and also to protect the cells against high osmotic pressures $[38,39]$.

Acetic and lactic acids, inhibitory compounds commonly found during fermentations that are typically produced by bacteria, were present during SSF of tests 2 and 3 but their concentrations, 0.3 to $2.2 \mathrm{mg} / \mathrm{mL}$ and 0.8 to $1.5 \mathrm{mg} / \mathrm{mL}$, respectively were unlikely to have inhibited yeast growth. The acetic acid concentrations were well below the critical concentration of $25 \mathrm{mg} / \mathrm{mL}$ reported to affect yeast growth and ethanol production [40]. Lactic acid can be formed from both hexoses and pentoses as a microbial metabolic product and is considered to be the most common contaminant in commercial fuel ethanol production facilities. Antibiotics are routinely used during fermentation to keep lactic acid below the critical concentration of $4 \mathrm{mg} /$ $\mathrm{mL}[40-42]$.
Ethanol production was measured at the end of the SSF after both 60 and $72 \mathrm{~h}$ for tests 2 and 3. Ethanol production decreased slightly from 60 to $72 \mathrm{~h}$ although the differences were not significant ( $P$ value $>0.05$, data not shown). This minor trend in the reduction of the ethanol concentration in tests 2 and 3 shows that fermentations were completed. Hence, the data after $60 \mathrm{~h}$ of SSF were used for comparisons among treatments (Fig. 7).

After $60 \mathrm{~h}$ of fermentation, ethanol production was significantly greater in cavitated treatments as compared to uncavitated treatments in all three tests (Tables 5, 6, and 7). The increases in ethanol production for cavitated treatments without cellulose amendment were 2.8 and $2.9 \%$ for PostCav and PostJet in test 2, respectively. In test 3, the increases were 2.2 and $0.7 \%$ for the PostCav and PostJet treatments, respectively (Table 6).

Uncavitated samples amended with cellulase also exhibited a significant increase in ethanol production of 4.1 and $2.2 \%$ for tests 2 and 3, respectively, as compared to unamended non-cavitated samples (Table 7). 


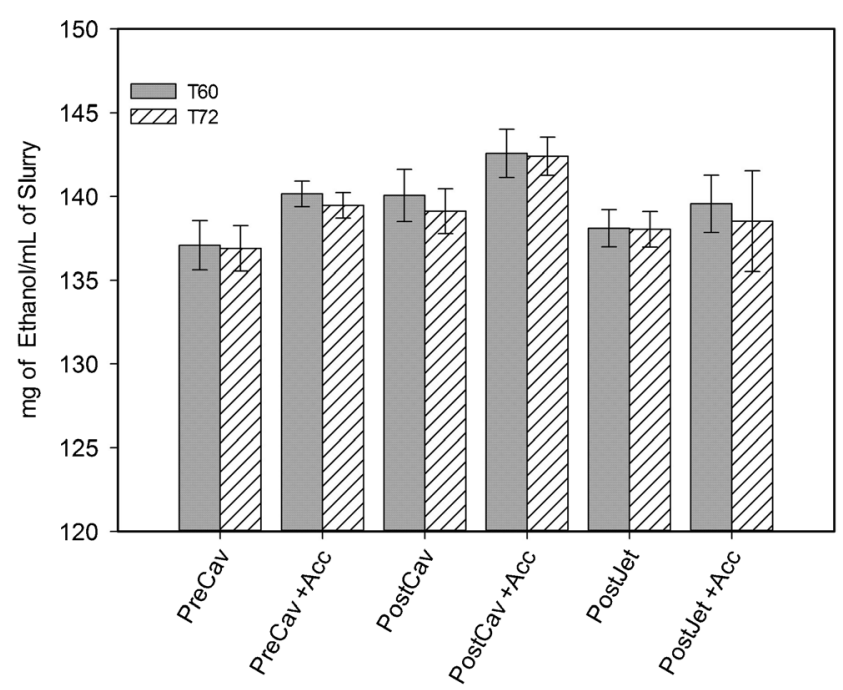

Fig. 7 Mean concentrations $(n=5)$ of ethanol $(\mathrm{mg} / \mathrm{L})$ after 60 and $72 \mathrm{~h}$ of SSF in cultures containing cavitated or uncavitated corn slurry with and without cellulase addition for test 3 . Test 2 shown similar trends (data not shown)

The greatest ethanol production improvement was seen in cavitated cultures amended with cellulase. In these cultures, significant increases in ethanol production of 4.7 and $4.8 \%$, for PostCav+Acc and PostJet+Acc were observed in test 2 (Table 7). In test 3, increases of 4.0 and $1.8 \%$ were observed for PostCav+Acc and PostJet+Acc treatments. The effects of cellulase and cavitation appeared to be additive and not synergistic. That is, the effects of cavitation and cellulase together were not greater than the sum of their individual effects.

The concentration of residual glucose in the form of glucose equivalents from residual saccharides and glucose was significantly greater in the cavitated and cavitatedcellulase-amended treatments, especially in the latter ones (data not shown). This was probably due to the presence of solubilized but unhydrolyzed lignocellulosic fractions from the corn grain.
$\mathrm{CO}_{2}$ production, as measured by weight loss during fermentation, was also greater in the cavitated and cavitatedcellulase-amended treatments (Tables 6 and 7). However, the differences in $\mathrm{CO}_{2}$ were not significant probably due to the larger error associated with weight loss measurement as compared to HPLC concentration measurements.

The total solids percent after SSF is an indication of the amount of the initial corn solids converted to products during SSF. The solids percent decreased more in those treatments that produced more ethanol (PostCav and PostJet) and in which more glucose was released from the corn grain (Table 8). Additional glucose release from treatments amended with cellulase was also reflected in the reduced solids in these treatments (Table 8). These results reflect the use of starch and cellulose for ethanol production and how cavitation and cellulase amendment improved the hydrolysis of corn grain and starch to ethanol and other products.

3.5 CFC and cellulase impacts on energy and economics of corn ethanol production

One important factor related to the use of new technologies to increase biofuel yield is the energy return on investment. The electrical energy used for cavitation in this work for the CFC unit was approximately 11,306 GJ (3,141 MWh) per year for a 379 million liter per year (100 million gallon per year) plant. The approximately $2 \%$ increase in ethanol production observed would result in an additional 7.6 million liters (2.0 million gallons) of ethanol per year worth more than US\$6 million. This ethanol would have an energy content (LHV) of approximately $160,360 \mathrm{GJ}(44,544 \mathrm{MWh})$. Therefore, the energy generated by cavitation in the form of increases in ethanol is approximately 16 times greater than the electricity expended. Furthermore, this indicates that $\mathrm{CFC}$ also enhanced the efficiency of the ethanol production process, and lead to an improved EROI value. Results from liquefaction and SSF

Table 6 Properties of PreCav (control), PostCav, and PostJet corn slurries after fermentation for $60 \mathrm{~h}$ for tests 2 and 3

\begin{tabular}{|c|c|c|c|c|c|c|}
\hline Treatment & Ethanol (mg/mL) & Lactic Ac. $(\mathrm{mg} / \mathrm{mL})$ & Glycerol (mg/mL) & Acetic Ac. (mg/mL) & $\mathrm{CO}_{2}(\%)$ & Ethanol increase (\%) \\
\hline \multicolumn{7}{|c|}{ SSF after $60 \mathrm{~h}$ for test 2} \\
\hline PreCav & $135.1 \pm 1.5 \mathrm{a}$ & $0.9 \pm 0.1 \mathrm{a}$ & $16.9 \pm 0.1 \mathrm{a}$ & $1.9 \pm 0.1 \mathrm{a}$ & $10.9 \pm 0.5 \mathrm{a}$ & - \\
\hline PostCav & $138.9 \pm 0.8 b$ & $0.8 \pm 0.3 \mathrm{a}$ & $17.2 \pm 0.4 \mathrm{a}$ & $2.2 \pm 0.3 \mathrm{a}$ & $11.4 \pm 0.9 \mathrm{a}$ & 2.8 \\
\hline PostJet & $139.1 \pm 0.7 \mathrm{~b}$ & $0.9 \pm 0.1 \mathrm{a}$ & $17.3 \pm 0.2 \mathrm{a}$ & $2.0 \pm 0.1 \mathrm{a}$ & $11.3 \pm 0.5 \mathrm{a}$ & 2.9 \\
\hline \multicolumn{7}{|c|}{ SSF after $60 \mathrm{~h}$ for test 3} \\
\hline PreCav & $137.1 \pm 1.5 \mathrm{a}$ & $1.3 \pm 0.0 \mathrm{a}$ & $16.1 \pm 0.1 \mathrm{a}$ & $0.9 \pm 0.2 \mathrm{a}$ & $10.2 \pm 0.5 \mathrm{a}$ & - \\
\hline PostCav & $140.1 \pm 1.6 b$ & $1.4 \pm 0.0 \mathrm{a}$ & $16.4 \pm 0.1 \mathrm{a}$ & $0.7 \pm 0.0 \mathrm{a}$ & $10.2 \pm 0.1 \mathrm{a}$ & 2.2 \\
\hline PostJet & $138.1 \pm 1.1 \mathrm{~b}$ & $1.5 \pm 0.1 \mathrm{a}$ & $15.8 \pm 1.3 \mathrm{a}$ & $0.8 \pm 0.4 \mathrm{a}$ & $10.1 \pm 0.0 \mathrm{a}$ & 1.0 \\
\hline
\end{tabular}

Values are means $(n=5)$ plus or minus one standard deviation. ANOVA was applied for each test at each compound and Tukey-Kramer's HSD test was conducted to identify difference among treatments. The same letter in each compound for each test denotes a homogenous group at level of significance of $5 \%$ 
Table 7 Properties of PreCav (control), PreCav+Acc, PostCav+Acc, and PostJet + Acc corn slurries after fermentation for $60 \mathrm{~h}$ for test 2 and 3

\begin{tabular}{|c|c|c|c|c|c|c|}
\hline Treatment & Ethanol $(\mathrm{mg} / \mathrm{mL})$ & Lactic Ac. $(\mathrm{mg} / \mathrm{mL})$ & Glycerol (mg/mL) & Acetic Ac. $(\mathrm{mg} / \mathrm{mL})$ & $\mathrm{CO}_{2}(\%)$ & Ethanol increase (\%) \\
\hline \multicolumn{7}{|c|}{$\mathrm{SSF}+\mathrm{ACC}$ after $60 \mathrm{~h}$ for test 2} \\
\hline PreCav & $135.1 \pm 1.5 \mathrm{a}$ & $0.9 \pm 0.1 \mathrm{a}$ & $16.9 \pm 0.1 \mathrm{a}$ & $1.9 \pm 0.1 \mathrm{a}$ & $10.9 \pm 0.5 \mathrm{a}$ & - \\
\hline PreCav+Acc & $140.7 \pm 0.5 b$ & $1.0 \pm 0.0 \mathrm{~b}$ & $16.5 \pm 0.1 b$ & $1.9 \pm 0.0 \mathrm{a}$ & $11.5 \pm 0.3 \mathrm{a}$ & 4.1 \\
\hline PostCav+Acc & $141.5 \pm 1.0 \mathrm{~b}$ & $1.0 \pm 0.0 \mathrm{~b}$ & $16.7 \pm 0.1 \mathrm{ab}$ & $1.9 \pm 0.0 \mathrm{ab}$ & $11.4 \pm 0.4 \mathrm{a}$ & 4.7 \\
\hline PostJet + Acc & $141.6 \pm 1.4 \mathrm{~b}$ & $0.9 \pm 0.0 \mathrm{a}$ & $16.8 \pm 0.2 \mathrm{a}$ & $2.0 \pm 0.1 \mathrm{~b}$ & $11.8 \pm 0.5 \mathrm{a}$ & 4.8 \\
\hline \multicolumn{7}{|c|}{$\mathrm{SSF}+\mathrm{ACC}$ after $60 \mathrm{~h}$ for test 3} \\
\hline PreCav & $137.1 \pm 1.5 \mathrm{a}$ & $1.3 \pm 0.1 \mathrm{a}$ & $16.1 \pm 0.1 \mathrm{a}$ & $0.9 \pm 0.2 \mathrm{a}$ & $10.2 \pm 0.5 \mathrm{a}$ & - \\
\hline PreCav+Acc & $140.2 \pm 0.8 b c$ & $1.4 \pm 0.0 \mathrm{a}$ & $15.4 \pm 0.1 \mathrm{ab}$ & $0.8 \pm 0.2 \mathrm{ab}$ & $10.4 \pm 1.7 \mathrm{a}$ & 2.3 \\
\hline PostCav+Acc & $142.6 \pm 1.4 \mathrm{~b}$ & $1.4 \pm 0.1 \mathrm{a}$ & $15.7 \pm 0.1 \mathrm{ab}$ & $0.4 \pm 0.1 \mathrm{bc}$ & $10.3 \pm 0.1 \mathrm{a}$ & 4.0 \\
\hline PostJet+Acc & $139.6 \pm 1.7 \mathrm{c}$ & $1.4 \pm 0.34 \mathrm{a}$ & $15.1 \pm 0.1 b$ & $0.4 \pm 0.3 \mathrm{c}$ & $10.7 \pm 0.3 \mathrm{a}$ & 1.8 \\
\hline
\end{tabular}

Values are means $(n=5)$ plus or minus one standard deviation. ANOVA was applied for each test at each compound and Tukey-Kramer's HSD test was conducted to identify difference among treatments. The same letter in each compound for each test denotes a homogenous group at level of significance of $5 \%$

(Fig. 5 and Tables 6 and 7) showed that PostCav and PosJet treatment always belonged to the same homogeneous group and that there was not a statistically significant difference between the two treatments at a $95 \%$ confidence level. Thus, CFC by itself improved the process. Although in this study the jet cooker did not have a positive effect, it may have other important functions [43]. On the other hand, use of CFC alone would eliminate the thermal energy used for the jet cooking system and further improve the EROI.

The energy return of the improved process with hydrodynamic cavitation would likely positively affect the EROI of ethanol production. Admittedly, considering the additional energy input by the cavitation pump and the additional energy output in the form of additional ethanol is a simplistic approach which does not consider other parameters. To better quantify the improvements on EROI, further research must also be conducted on downstream processes to identify secondary effects on, for example, distillation and co-product recovery and value.

From a purely economic standpoint, for the plants' electricity cost of US $\$ 0.014 / \mathrm{MJ}$ (US $\$ 0.05 / \mathrm{kWh}$ ), and an ethanol fuel value of US $\$ 0.79 / \mathrm{L}$ (US $\$ 3 /$ gallon), the

Table 8 Slurry solids in percentage of dry matter (\% DM) before and after commercial scale controlled flow cavitation treatment and after cavitation and jet cooking with and without cellulase, after SSF

\begin{tabular}{ll}
\hline Treatment & Slurry solids \% DM \\
\hline Control (PreCav) & $8.5 \pm 0.2$ \\
Cavitation (PostCav) & $8.3 \pm 0.0$ \\
Cavitation+Jet Cook (PostJet) & $8.4 \pm 0.1$ \\
Control+Acc (PreCav+Acc) & $8.1 \pm 0.1$ \\
Cavitation+Acc (PostCav+Acc) & $7.8 \pm 0.2$ \\
Cavitation+Jet Cook+Acc (PostJet+Acc) & $8.0 \pm 0.2$ \\
\hline
\end{tabular}

electricity cost for running the CFC unit (US $\$ 157,050 /$ year) would be a small fraction ( $2.6 \%$ ) of the value of the additional ethanol fuel generated by cavitation (US $\$ 6,000,000 /$ year).

Overall, the results show that cellulase amendment increased the yield of ethanol by more than $4 \%$ when it was used with uncavitated samples and by $1.7 \%$ when it was used with cavitated sample. These values are near the theoretical amount of ethanol that could be produced from the cellulose fraction in corn assuming a composition of $0.07 \mathrm{~g}$ cellulose per gram of corn (maximum ethanol yield $=0.050 \mathrm{~mL}$ ethanol per $g$ of corn). However, there are other ways that cellulase may have improved ethanol production. For example, if cellulose hydrolysis promoted recalcitrant starch release [26].

The increase in ethanol production due to cellulase must be balanced with the cost of the enzymes needed to achieve this gain. There is limited information on the commercial cost of the cellulase preparation used in this study (Accellerase ${ }^{\circledR}$ 1500). Studies on the costs of cellulase enzyme production have shown that the cost varies significantly among different references [12, 14, 27, 44]. In addition, the value is generally reported in units of dollars per gallon of biofuel which obfuscates the direct cost of producing the enzyme [45]. However, in a techno-economic analysis by KleinMarcuschamer et al. [45], the cost of cellulase production is reported to be approximately US $\$ 10.14 \mathrm{~kg}^{-1}$.

In this study, cellulase was added at a rate of $0.35 \mathrm{~mL}$ per gram of cellulose (cellulose content in yellow dent corn is around $0.07 \mathrm{~g}$ of cellulose per gram of corn), which is within the range recommended by the manufacturer. At this dosage, the cellulase cost per additional liter of ethanol would be greater than US $\$ 10$ which would be cost prohibitive. Future studies will investigate whether lower dosages of cellulase are effective at increasing ethanol production when used in conjunction with CFC. It is possible that at lower concentrations, synergistic effects with CFC would be 
observed and that this could potentially reduce the costs of using these enzymes at dry mill ethanol plants to convert corn fiber fractions to ethanol.

\section{Conclusions}

In summary, these experiments revealed that while slurry properties at a dry-mill ethanol plant varied from batch to batch (or test), the effects of CFC and cellulase amendment on improving starch and cellulose conversion and increasing ethanol production were consistent.

The results show that cavitation altered the particle size distribution led to qualitative changes in cell structure observable by SEM, increased the total sugars after liquefaction, reduced the total solids after liquefaction, and led to significant increases in ethanol production and solids conversion during SSF. The effect of CFC alone was greater than the effect of cavitation plus jet cooking, possibly due to the formation of unfermentable products or solids during jet cooking. Cellulase addition further significantly increased the yield of ethanol as well as solids losses in all three tests.

A simple energy and economic analysis conducted to make inferences about the ability of CFC to improve the EROI and economics of ethanol production showed that the energy return of CFC in the form of ethanol is 16 times greater than the energy expended to generate the cavitation. Furthermore, the value of the extra ethanol produced by $\mathrm{CFC}$ was 38 times more than the cost of the electricity used for the CFC system.

These results indicate that CFC may be an effective and economical process to improve the efficiency of commercialscale corn ethanol production.

Acknowledgments The authors gratefully acknowledge support provided for this project from the Ohio Third Frontier program and The Colombian Science Foundation (COLCIENCIAS) and the Ohio Agricultural Research and Development Center Genencor Corp provided material support. The authors also want to thank Dr. Sukhbir Grewal for all her support during this project; the OSU Molecular and Cellular Imaging Center for assistance with electron micrography; and Scott Incorvia, Fred Clarke, and Parker Lyle of Arisdyne Systems for design, development, and installation of the commercial-scale cavitation unit.

Open Access This article is distributed under the terms of the Creative Commons Attribution License which permits any use, distribution, and reproduction in any medium, provided the original author(s) and the source are credited.

\section{References}

1. Renewable Fuels Association RFA (2012) Ethanol Industry Statistics. Renewable Fuels Association. http://www.ethanolrfa.org/ pages/statistics. Accessed 17 October 2012
2. Noureddini H, Byun J (2010) Dilute-acid pretreatment of distillers' grains and corn fiber. Bioresour Technol 101(3):1060-1067. doi:10. 1016/j.biortech.2009.08.094

3. Kim Y, Mosier NS, Hendrickson R, Ezeji T, Blaschek H, Dien B, Cotta M, Dale B, Ladisch MR (2008) Composition of corn dry-grind ethanol by-products: DDGS, wet cake, and thin stillage. Bioresour Technol 99(12):5165-5176. doi:10.1016/j.biortech.2007.09.028

4. Liu K (2009) Effects of particle size distribution, compositional and color properties of ground corn on quality of distillers dried grains with solubles (DDGS). Bioresour Technol 100(19):4433-4440. doi: 10.1016/j.biortech.2009.02.067

5. Bothast RJ, Schlicher MA (2005) Biotechnological processes for conversion of corn into ethanol. Appl Microbiol Biotechnol 67(1): 19-25. doi:10.1007/s00253-004-1819-8

6. Shapouri H, Duffield JA, Graboski MS, United States. Dept. of Agriculture. Economic Research S (1995) Estimating the net energy balance of corn ethanol : an Economic Research Service report. U.S. Dept. of Agriculture, ERS, Washington, DC

7. Shapouri H, Duffield JA, Wang M, United States. Dept. of Agriculture. Office of the Chief E, United States, Dept. of Agriculture. Office of Energy P, New U (2002) The energy balance of corn ethanol an update. U.S. Dept. of Agriculture, Office of the Chief Economist. Office of Energy Policy and New Uses, Washington, DC

8. Shapouri H, Gallagher PW, Nefstead W, Schwartz R, Noe S, Conway R (2010) 2008 Energy Balance for the Corn Ethanol Industry. Agricultural Economic Report. United States Department of Agriculture (USDA), Washington, DC

9. Pimentel D (2001) The Limits of Biomass Energy, vol 2. Encyclopedia of physical science and technology, 3rd edn. Academic Press, California

10. Pimentel D (2003) Ethanol Fuels: Energy Balance, Economics, and Environmental Impacts Are Negative. Nat Resour Res 12(2):127134

11. Murphy D, Hall CS, Powers B (2011) New perspectives on the energy return on (energy) investment (EROI) of corn ethanol. Environ Dev Sustain 13(1):179-202. doi:10.1007/s10668-0109255-7

12. Kazi FK, Fortman JA, Anex RP, Hsu DD, Aden A, Dutta A, Kothandaraman G (2010) Techno-economic comparison of process technologies for biochemical ethanol production from corn stover. Fuel 89(Supplement 1):S20-S28. doi:10.1016/j.fuel.2010.01.001

13. Farrell AE, Plevin RJ, Turner BT, Jones AD, O'Hare M, Kammen DM (2006) Ethanol can contribute to energy and environmental goals. Science (New York, NY) 311(5760):506-508

14. Sassner P, Galbe M, Zacchi G (2008) Techno-economic evaluation of bioethanol production from three different lignocellulosic materials. Biomass Bioenergy 32(5):422-430. doi:10.1016/j.biombioe.2007. 10.014

15. Montalbo-Lomboy M (2010) Ultrasonic pretreatment for enhanced saccharification and fermentation of ethanol production from corn. Dissertation, Iowa State University, Iowa, United States

16. Gogate PR, Tayal RK, Pandit AB (2006) Cavitation: A technology on the horizon. Curr Sci 91(1):35-46

17. Suslick KS (1990) Sonochemistry. Science 247(4949):1439-1445

18. Flint EB, Suslick KS (1991) The temperature of cavitation. Science 253(5026):1397-1399

19. Gogate PR, Pandit AB (2005) A review and assessment of hydrodynamic cavitation as a technology for the future. Ultrason Sonochem 12(1-2):21-27. doi:10.1016/j.ultsonch.2004.03.007

20. Montalbo-Lomboy M, Johnson L, Khanal SK, van Leeuwen J, Grewell D (2010) Sonication of sugary-2 corn: A potential pretreatment to enhance sugar release. Bioresour Technol 101(1): 351-358. doi:10.1016/j.biortech.2009.07.075

21. Montalbo-Lomboy M, Khanal SK, van Leeuwen J, Raj Raman D, Dunn L Jr, Grewell D (2010) Ultrasonic pretreatment of corn slurry for 
saccharification: A comparison of batch and continuous systems. Ultrason Sonochem 17(5):939-946. doi:10.1016/j.ultsonch.2010.01.013

22. Nikolic S, Mojovic L, Rakin M, Pejin D, Pejin J (2010) Ultrasound-assisted production of bioethanol by simultaneous saccharification and fermentation of corn meal. Food Chem 122(1):216-222. doi:10.1016/j.foodchem.2010.02.063

23. Gogate PR (2008) Cavitational reactors for process intensification of chemical processing applications: A critical review. Chem Eng Process Process Intensif 47(4):515-527. doi:10.1016/j.cep.2007.09.014

24. Kozyuk O (2010) Apparatus and method for increasing alcohol yield from grain, US Patent 7667082 B2, issued February 23, 2010. U.S. Patent and Trademark Office, Alexandria

25. Porter SE, Donohoe BS, Beery KE, Xu Q, Ding S-Y, Vinzant TB, Abbas CA, Himmel ME (2007) Microscopic analysis of corn fiber using starch- and cellulose-specific molecular probes. Biotechnol Bioeng 98(1):123-131. doi:10.1002/bit.21409

26. Gulati M, Kohlmann K, Ladisch MR, Hespell R, Bothast RJ (1996) Assessment of ethanol production options for corn products. Bioresour Technol 58(3):253-264. doi:10.1016/s0960-8524(96)00108-3

27. Wingreini A, Galbe M, Roslander C, Rudolf A, Zacchi G (2005) Effect of Reduction in Yeast and Enzyme Concentrations in a Simultaneous-Saccharification-and-Fermentation-Based Bioethanol Process. In: Davison B, Evans B, Finkelstein M, McMillan J (eds) Twenty-Sixth Symposium on Biotechnology for Fuels and Chemicals. ABAB Symposium. Humana Press, New York, pp 485-499. doi:10.1007/978-1-59259-991-2 43

28. Ladisch M, Dale B, Tyner W, Mosier N, Kim Y, Cotta M, Dien B, Blaschek H, Laurenas E, Shanks B, Verkade J, Schell C, Petersen G (2008) Cellulose conversion in dry grind ethanol plants. Bioresour Technol 99(12):5157-5159. doi:10.1016/j.biortech.2007.09.082

29. Kim Y, Mosier N, Ladisch MR (2008) Process simulation of modified dry grind ethanol plant with recycle of pretreated and enzymatically hydrolyzed distillers' grains. Bioresour Technol 99(12):5177-5192. doi:10.1016/j.biortech.2007.09.035

30. Dowe N, McMillan J (2008) SSF experimental protocolslignocellulosic biomass hydrolysis and fermentation. Laboratory Analytical Procedure (LAP) Technical Report NREL/TP-510$42630 \mathrm{http}: / / w w w . n r e l . g o v / b i o m a s s / p d f s / 42630 . p d f$.

31. Sluiter A, Hames B, Hyman D, Payne C, Ruiz R, Scarlata C, Sluiter J, Templeton D, Wolfe J (2008) Determination of total solids in biomass and total dissolved solids in liquid process samples. Laboratory Analytical Procedure (LAP) Technical Report NREL/TP-510$42621 \mathrm{http}: / /$ www.nrel.gov/biomass/pdfs/42621.pdf

32. Smith W, Betrán J, Runge ECA (2004) Corn: origin, history, technology, and production, 1 st edn. Wiley Series in Crop Sciences, Hoboken
33. Khanal SK, Montalbo M, van Leeuwen J, Srinivasan G, Grewell D (2007) Ultrasound enhanced glucose release from corn in ethanol plants. Biotechnol Bioeng 98(5):978-985. doi:10.1002/bit.21497

34. Hoseney CR (1994) Principles of cereal science and technology, 2nd edn. American Association of Cereal Chemists Inc, St. Paul

35. Ma Y, Cai C, Wang J, Sun D-W (2006) Enzymatic hydrolysis of corn starch for producing fat mimetics. J Food Eng 73(3):297-303. doi:10. 1016/j.jfoodeng.2005.01.023

36. Wu X, Zhao R, Wang D, Bean SR, Seib PA, Tuinstra MR, Campbell M, O'Brien A (2006) Effects of Amylose, Corn Protein, and Corn Fiber Contents on Production of Ethanol from Starch-Rich Media1. Cereal Chem J 83(5):569-575. doi:10.1094/cc-83-0569

37. Case SE, Capitani T, Whaley JK, Shi YC, Trzasko P, Jeffcoat R, Goldfarb HB (1998) Physical Properties and Gelation Behavior of a Low-Amylopectin Maize Starch and Other High-Amylose Maize Starches. J Cereal Sci 27(3):301-314. doi:10.1006/jcrs.1997.0164

38. Zamora F (2009) Biochemistry of alcoholic fermentation. In: Moreno-Arribas MV, Polo MC (eds) Wine Chemistry and Biochemistry. Springer, New York, pp 3-26

39. Michnick S, Roustan JL, Remize F, Barre P, Dequin S (1997) Modulation of Glycerol and Ethanol Yields During Alcoholic Fermentation in Saccharomyces cerevisiae Strains Overexpressed or Disrupted for GPD1 Encoding Glycerol 3-Phosphate Dehydrogenase. Yeast 13(9):783-793. doi:10.1002/(sici)10970061(199707)13:9<783::aid-yea128>3.0.co;2-w

40. Narendranath NV, Thomas KC, Ingledew WM (2001) Acetic acid and lactic acid inhibition of growth of Saccharomyces cerevisiae by different mechanisms. J Am Soc Brew Chem 59(4):187-194

41. Skinner KA, Leathers TD (2004) Bacterial contaminants of fuel ethanol production. J Ind Microbiol Biotechnol 31(9):401-408. doi: 10.1007/s10295-004-0159-0

42. Graves T, Narendranath N, Dawson K, Power R (2006) Effect of pH and lactic or acetic acid on ethanol productivity by Saccharomyces cerevisiae in corn mash. J Ind Microbiol Biotechnol 33(6):469-474. doi:10.1007/s10295-006-0091-6

43. Kelsall DR, Lyons TP (2003) Grain dry milling and cooking for alcohol production. In: Press. NU (ed) The Alcohol Textbook, 2nd edn. Nottingham University Press, Nottingham, pp 9-22

44. Wingren A, Galbe M, Zacchi G (2003) Techno-Economic Evaluation of Producing Ethanol from Softwood: Comparison of SSF and SHF and Identification of Bottlenecks. Biotechnol Prog 19(4):1109-1117. doi:10.1021/bp0340180

45. Klein-Marcuschamer D, Oleskowicz-Popiel P, Simmons BA, Blanch HW (2012) The challenge of enzyme cost in the production of lignocellulosic biofuels. Biotechnol Bioeng 109(4):1083-1087. doi: 10.1002/bit.24370 